\title{
Sulfated Polysaccharides from Macroalgae Are Potent Dual Inhibitors of Human ATP-Hydrolyzing Ectonucleotidases NPP1 and CD39
}

\author{
Vittoria Lopez $^{1,2}{ }^{(D}$, Laura Schäkel ${ }^{1,2}$, H. J. Maximilian Schuh ${ }^{3}$, Michael S. Schmidt ${ }^{3}$, Salahuddin Mirza ${ }^{1,2}$, \\ Christian Renn ${ }^{1,2}$, Julie Pelletier ${ }^{4}$, Sang-Yong Lee ${ }^{1,2}$, Jean Sévigny ${ }^{4,5} \mathbb{D}$, Susanne Alban ${ }^{6}\left(\mathbb{D}\right.$, Gerd Bendas $^{3}$ and \\ Christa E. Müller 1,2,*iD
}

1 Pharmaceutical \& Medicinal Chemistry, Pharmaceutical Institute, University of Bonn, An der Immenburg 4, 53121 Bonn, Germany; vlopez@uni-bonn.de (V.L.); laura.schaekel@uni-bonn.de (L.S.); salahuddinmirza@gmail.com (S.M.); christian.renn@posteo.de (C.R.); s6saleee@uni-bonn.de (S.-Y.L.)

2 PharmaCenter Bonn, University of Bonn, An der Immenburg 4, 53121 Bonn, Germany

3 Pharmaceutical \& Cell Biological Chemistry, Pharmaceutical Institute, University of Bonn, An der Immenburg 4, 53121 Bonn, Germany; maxschuh@uni-bonn.de (H.J.M.S.); michael.sebastian.schmidt@uni-bonn.de (M.S.S.); gbendas@uni-bonn.de (G.B.)

4 Centre de Recherche du CHU de Québec-Université Laval, Québec City, QC G1V 4G2, Canada; julie.pelletier@crchudequebec.ulaval.ca (J.P.); jean.Sevigny@crchudequebec.ulaval.ca (J.S.)

5 Départment de Microbiologie-Infectiologie et d'Immunologie, Faculté de Médecine, Université Laval, Quebec City, QC G1V 0A6, Canada

6 Pharmaceutical Institute, Christian-Albrechts-University of Kiel, Gutenbergstraße 76, 24118 Kiel, Germany; salban@pharmazie.uni-kiel.de

* Correspondence: christa.mueller@uni-bonn.de; Tel.: +49-228-73-2301; Fax: +49-228-73-2567

Citation: Lopez, V.; Schäkel, L.; Schuh, H.J.M.; Schmidt, M.S.; Mirza, S.; Renn, C.; Pelletier, J.; Lee, S.-Y.; Sévigny, J;; Alban, S.; et al. Sulfated Polysaccharides from Macroalgae Are Potent Dual Inhibitors of Human ATP-Hydrolyzing Ectonucleotidases NPP1 and CD39. Mar. Drugs 2021, 19, 51. https://doi.org/10.3390/md 19020051

Received: 29 December 2020

Accepted: 15 January 2021

Published: 22 January 2021

Publisher's Note: MDPI stays neutral with regard to jurisdictional claims in published maps and institutional affiliations.

Copyright: (c) 2021 by the authors. Licensee MDPI, Basel, Switzerland. This article is an open access article distributed under the terms and conditions of the Creative Commons Attribution (CC BY) license (https:// creativecommons.org/licenses/by/ $4.0 /)$.

\begin{abstract}
Extracellular ATP mediates proinflammatory and antiproliferative effects via activation of P2 nucleotide receptors. In contrast, its metabolite, the nucleoside adenosine, is strongly immunosuppressive and enhances tumor proliferation and metastasis. The conversion of ATP to adenosine is catalyzed by ectonucleotidases, which are expressed on immune cells and typically upregulated on tumor cells. In the present study, we identified sulfopolysaccharides from brown and red sea algae to act as potent dual inhibitors of the main ATP-hydrolyzing ectoenzymes, ectonucleotide pyrophosphatase/phosphodiesterase-1 (NPP1) and ecto-nucleoside triphosphate diphosphohydrolase-1 (NTPDase1, CD39), showing nano- to picomolar potency and displaying a non-competitive mechanism of inhibition. We showed that one of the sulfopolysaccharides tested as a representative example reduced adenosine formation at the surface of the human glioblastoma cell line U87 in a concentration-dependent manner. These natural products represent the most potent inhibitors of extracellular ATP hydrolysis known to date and have potential as novel therapeutics for the immunotherapy of cancer.
\end{abstract}

Keywords: adenosine; CD39; ectonucleotidase inhibitors; fucoidan; immuno-oncology; NPP1; NTPDase1; macroalgae constituents; sulfated polysaccharides

\section{Introduction}

Nucleosides and nucleotides, e.g., adenosine, ATP and ADP, act as extracellular signaling molecules activating P1 (adenosine) or P2 (nucleotide) receptors [1-5]. Adenosine receptors are G protein-coupled receptors (GPCRs), while P2 receptors are further subdivided into P2Y (GPCRs) and P2X (ligand-gated ion channel) receptor subtypes. Nucleotides can be converted by a cascade of ectonucleotidases to adenosine (see Figure 1). Many tumor cells overexpress ectonucleotidases that metabolize proinflammatory ATP to adenosine, which exerts immunosuppressive, angiogenic, prometastatic and tumor growth promoting activities [5]. Ectonucleotidase inhibition has therefore been proposed as a novel approach for cancer immunotherapy [6,7]. Different classes of ectonucleotidases exist including 
nucleotide pyrophosphatase/phosphodiesterases (NPPs), nucleoside triphosphate diphosphohydrolases (NTPDases), alkaline phosphatases (AP) and ecto-5' ${ }^{\prime}$-nucleotidase (cluster of differentiation 73 (CD73)). The NPP family consists of seven structurally related ectoenzymes (NPP1-NPP7), four of which are known to hydrolyze extracellular nucleotides $[1,2,8]$. NPP1 (CD203a, also known as PC-1 (plasma cell antigen-1), EC 3.1.4.1) and NPP3 catalyze the hydrolysis of a variety of nucleotides including nucleoside triphosphates (e.g., ATP and $\mathrm{UTP}$ ), dinucleotide polyphosphates (e.g., $\mathrm{Ap}_{3} \mathrm{~A}$ and $\mathrm{Ap}_{4} \mathrm{~A}$ ), cyclic dinucleotides (e.g., $2^{\prime}, 3^{\prime \prime}$-cGAMP) and nucleotide sugars (e.g., UDP-glucose and ADP-ribose) [9-12], NPP1 preferentially hydrolyzes ATP into AMP and PPi. NPP4 was reported to hydrolyze the physiological dinucleotides $\mathrm{Ap}_{3} \mathrm{~A}$ and $\mathrm{Ap}_{4} \mathrm{~A}$, while ATP hydrolysis by this enzyme is negligible [11]. NPP5 has recently been reported to hydrolyze nicotinamide adenine dinucleotide $\left(\mathrm{NAD}^{+}\right)$[13]. Other members of the NPP family, i.e., NPP2 (autotaxin), NPP6 and NPP7 (alkaline sphingomyelinase) act as phospholipases [8]. The NTPDase family comprises eight members (NTPDase 1-8), NTPDase1 (CD39, EC 3.6.1.5) being the most prominent member of this family in blood vessels and at the surface of leukocytes. They catalyze the hydrolysis of extracellular nucleoside tri- and diphosphates by cleaving off phosphate [8]. Ecto-5'-nucleotidase (CD73) hydrolyzes nucleoside monophosphates, e.g., AMP, to the corresponding nucleoside, e.g., adenosine. Thus, proinflammatory, antiproliferative ATP can be converted by subsequent action of NPP1 or CD39 and CD73 to immunosuppressive adenosine (Figure 1), which then accumulates in the tumor environment leading to immune escape of the tumor.

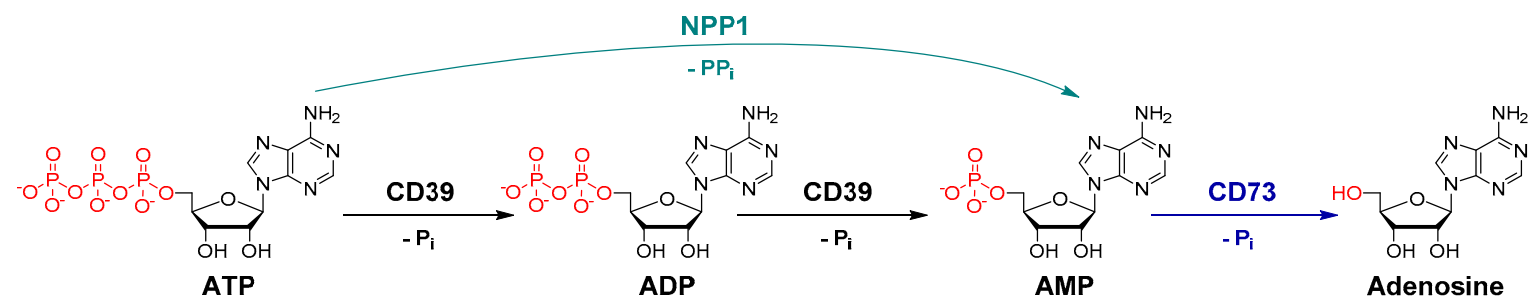

Figure 1. Hydrolysis of ATP to adenosine catalyzed by the key ectonucleotidases NPP1, CD39 and CD73 ( $\mathrm{P}_{\mathrm{i}}$, inorganic phosphate).

Recently, there has been an enormous interest in identifying and developing ectonucleotidase inhibitors, antibodies and small molecules, as novel cancer immunotherapeutics $[4,6,7]$.

Several antibodies and small molecules have been developed for blocking the AMPhydrolyzing, adenosine-producing ectoenzyme CD73, and the first drugs are currently evaluated in clinical trials for the immunotherapy of cancer to prevent the formation of immunosuppressive adenosine [14]. The blockade of enzymes that hydrolyze extracellular ATP to AMP could be even more efficient since it would lead to the accumulation of antiproliferative ATP in addition to preventing the formation of immunosuppressive adenosine due to the depletion of AMP as a CD73 substrate.

On the other hand, ATP, which acts on different subtypes of P2Y (G protein-coupled) and P2X (ligand-gated ion channel) receptors that are activated by different ATP concentrations depending on the receptor subtype, can also display proinflammatory effects since they belong to the danger-associated molecular patterns (DAMPs) [15]. In these cases, inhibition of ATP hydrolysis may result in proinflammatory effects.

So far, only moderately potent and/or non-selective NPP1 and CD39 inhibitors have been described, which can be divided into nucleotides and non-nucleotides. $N^{6}$-Diethyl$\beta, \gamma$-dibromomethylene-ATP (ARL 67156, 1) is a weak dual CD39/CD73 inhibitor with low metabolic stability $[16,17]$. Several other negatively charged compound classes including (poly)sulfonates such as suramin (2) and sulfoanthraquinones [18-20], and polyoxometalates (POMs), e.g., $\left[\mathrm{TiW}_{11} \mathrm{CoO}_{40}\right]^{8-}(3)$ and $\left[\mathrm{Co}_{4}\left(\mathrm{H}_{2} \mathrm{O}\right)_{2}\left(\mathrm{PW}_{9} \mathrm{O}_{34}\right)_{2}\right]^{10-}$ (4) $[21,22]$, were found to inhibit CD39 and/or NPP1. A selection of the most potent NPP1 and CD39 inhibitors is depicted in Figure 2. 


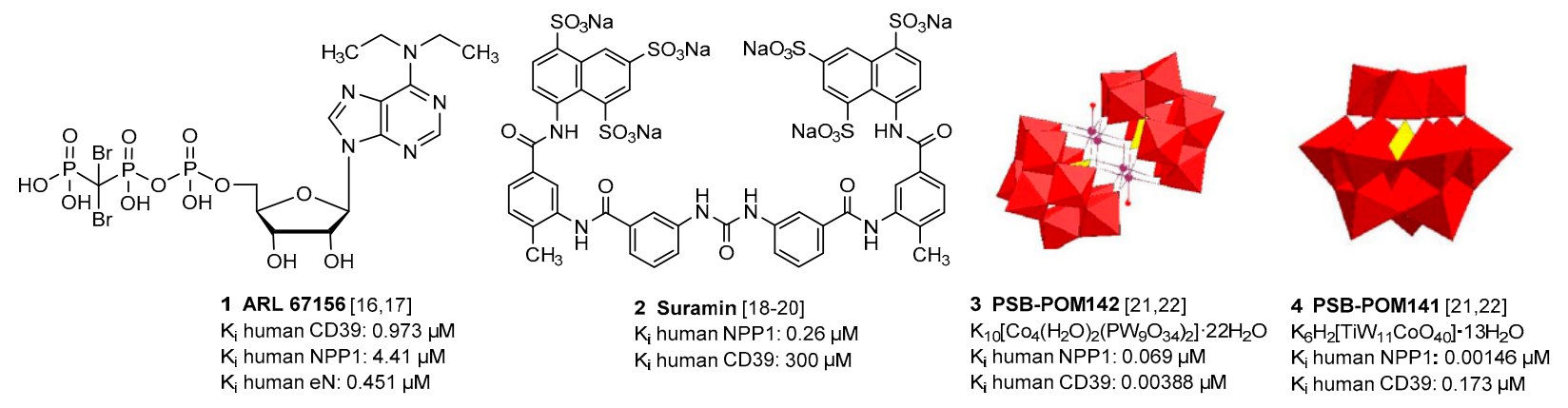

Figure 2. Selected inhibitors of ectonucleotidases NPP1 and CD39.

Sulfated polysaccharides from sea algae, in particular fucoidans present in brown algae, e.g., from Sargassum polycystum [23], have been reported to possess antitumor activity in vitro and in vivo [24-27]. These natural products were shown to inhibit cell growth directly, e.g., by inducing apoptosis, and, in addition, to activate the immune system in its fight against cancer [28-30]. Their molecular mechanism of action is not fully understood at present, and the molecular targets are largely unknown [31]. This prompted us to study exemplary polysaccharides from red and brown algae, which are negatively charged like reported ectonucleotidase inhibitors (Figure 2), for inhibitory effects on these enzymes.

\section{Results and Discussion}

Four sulfated polysaccharides 5-8 (Table 1), extracted from different algae species, were investigated in the present study as potential inhibitors of ectonucleotidases. Compounds 5 and 8 represent sulfated xylogalactans from red algae, compounds $\mathbf{6}$ and $\mathbf{7}$ are brown algae-derived fucoidans. They were extracted, purified and chemically characterized as previously described [32-34]. The chemical characteristics of the used batches are shown in Tables 1 and 2.

Table 1. Basic characteristics of investigated sulfated algae polysaccharides.

\begin{tabular}{cccccccc}
\hline Compound & $\begin{array}{c}\text { Type of Sulfated } \\
\text { Polysaccharide }\end{array}$ & $\begin{array}{c}\text { Extracted Alga } \\
\text { Species }\end{array}$ & $\begin{array}{c}\text { Degree of } \\
\text { Sulfation }\end{array}{ }^{\mathbf{a}}$ & Molar Mass (kDa) $^{\mathbf{b}}$ & Proteins (\%) $^{\mathbf{c}}$ & Uronic Acids (\%) $^{\mathbf{d}}$ \\
\hline $\mathbf{5}$ & Xylogalactan & Delesseria sanguinea & $0.65 \pm 0.02$ & $214 \pm 28$ & $7.24 \pm 0.07$ & $3.96 \pm 0.54$ \\
\hline $\mathbf{6}$ & Fucoidan & Saccharina latissima & $0.52 \pm 0.01$ & $534 \pm 11$ & $8.08 \pm 0.09$ & $7.42 \pm 0.18$ \\
\hline $\mathbf{7}$ & Fucoidan & Fucus vesiculosus & $0.59 \pm 0.01$ & $38 \pm 1$ & $7.07 \pm 1.59$ & $0.27 \pm 0.27$ \\
\hline $\mathbf{8}$ & Xylogalactan & Coccotylus truncatus & $0.52 \pm 0.01$ & $128 \pm 4$ & $3.74 \pm 1.29$ & $9.50 \pm 0.23$ \\
\hline
\end{tabular}

a Average number of sulfate groups per monosaccharide related to the total glycan content; it was calculated by means of the $\mathrm{SO}_{3} \mathrm{Na}$, which was derived from $\%$ sulfur content determined by elemental analysis (mean $\pm \mathrm{SD}, n=2$ ). ${ }^{\mathrm{b}}$ Mean weight average molar mass, determined by SEC-MALS-RI, mean $\pm \mathrm{SD}$ (mean $\pm \mathrm{SD}, n=3$ ). ${ }^{\mathrm{c}}$ The content of protein was calculated by elemental analysis (\% nitrogen) (mean $\pm \mathrm{SD}, n=2) .{ }^{\mathrm{d}}$ Determined according to the method of Blumenkrantz et al. [35] and Filisetti-Cozzi et al. [36] $(\mathrm{mean} \pm \mathrm{SD}, n=2 \times 2)$.

Table 2. Composition of investigated sulfated algae polysaccharides. ${ }^{\mathrm{a}}$

\begin{tabular}{|c|c|c|c|c|c|c|c|}
\hline Compound & $\begin{array}{l}\text { Type of Sulfated } \\
\text { Polysaccharide }\end{array}$ & $\begin{array}{l}\text { Fucose } \\
(\mathrm{mol} \%)\end{array}$ & Galactose (mol\%) & $\begin{array}{l}\text { Xylose } \\
(\mathrm{mol} \%)\end{array}$ & $\begin{array}{c}\text { Mannose } \\
(\mathrm{mol} \%)\end{array}$ & $\begin{array}{l}\text { Glucose } \\
(\mathrm{mol} \%)\end{array}$ & $\begin{array}{l}\text { Rhamnose } \\
\text { (mol\%) }\end{array}$ \\
\hline 5 & Xylogalactan & 0.0 & 75.3 & 16.1 & 2.5 & 6.1 & 0.0 \\
\hline 6 & Fucoidan & 53.4 & 13.6 & 6.7 & 5.4 & 19.8 & 1.3 \\
\hline 7 & Fucoidan & 83.1 & 7.3 & 6.5 & 2.0 & 0.4 & 0.7 \\
\hline 8 & Xylogalactan & 0.0 & 87.6 & 3.8 & 6.7 & 2.0 & 0.0 \\
\hline
\end{tabular}

${ }^{a}$ Determined according to the method of Blakeney et al. [37]. 
We initially tested the effects of the compounds at a concentration of $20,000 \mathrm{ng} / \mathrm{mL}$ on the most prominent ectonucleotidase families, NPPs (NPP1, 3, 4 and 5), NTPDases (NTPDase1, 2, 3 and 8) and CD73 (see Figure 3).

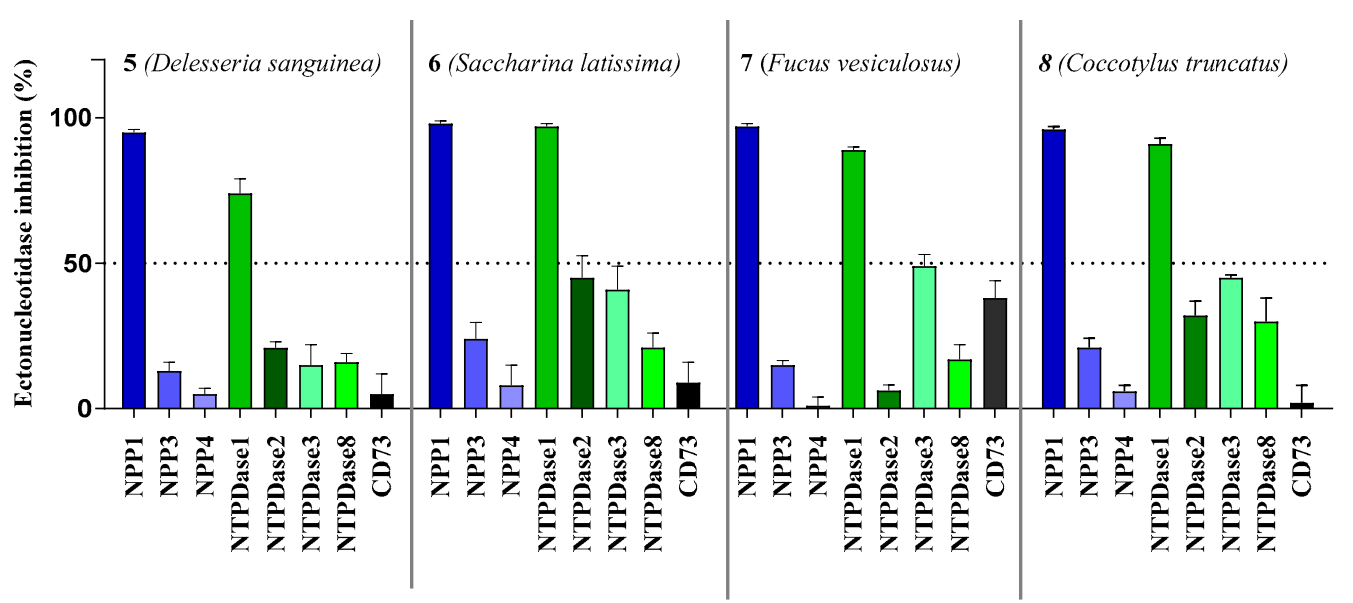

Figure 3. Ectonucleotidase inhibition by sulfopolysaccharides 5-8 extracted from sea algae. Compounds were tested at a concentration of 20,000 ng/mL. NPP1 and NTPDase2, 3 and 8 activities were analyzed using a CE-based assay employing ATP as a substrate as described in the experimental section; NPP3 was investigated using $p$-Nph- $5^{\prime}$-TMP as a substrate (see Section 3.2 for details); NPP4 was tested with $\mathrm{Ap}_{4} \mathrm{~A}$ as a substrate using a luciferase assay (for details see Section 3.3); NTPDase1 (CD39) activity was determined with a malachite green assay, or a CE-based assay, respectively (see Section 3.4 for details). The data is normalized with respect to positive $(100 \%)$ and negative $(0 \%)$ controls.

All compounds showed the highest inhibition of NPP1, which was completely inhibited at the test concentration, combined with high selectivity versus the other NPP subtypes. The second highest inhibition was observed at NTPDase1 (CD39) while inhibition of all other enzymes was below $50 \%$. As a next step, we investigated concentration-dependent inhibition by determining full concentration-inhibition curves for all four compounds at NPP1 and CD39, and determined the compounds' $K_{i}$ values (see Table 3). Curves for compound 7 as a representative inhibitor are depicted in Figure 4. Compound 7 was selected because it showed the lowest molecular weight of all tested sulfated polysaccharides and was available in high quantity.

Table 3. Potencies of investigated compounds at ectonucleotidases NPP1 and CD39 in comparison to standard inhibitors.

\begin{tabular}{|c|c|c|c|}
\hline Compound & $\begin{array}{l}\text { Compound Name } \\
\text { or Algal Species }\end{array}$ & $\begin{array}{c}\text { Human NPP1 } \\
\mathrm{Ki} \pm \text { SEM (nM) }\end{array}$ & $\begin{array}{c}\text { Human CD39 } \\
\text { Ki } \pm \text { SEM (nM) }\end{array}$ \\
\hline \multicolumn{4}{|c|}{ Standard ectonucleotidase inhibitors } \\
\hline 1 & ARL 67156 & $973 \pm 239[14]^{a}$ & $4410 \pm 3,530[14]^{b}$ \\
\hline 2 & Suramin & $780 \pm 81[38]^{b}$ & $300,000 \pm 100[18]^{b}$ \\
\hline 3 & PSB-POM142 & $690 \pm 4[22]^{b}$ & $3.88 \pm 1.40[22]^{\mathrm{c}}$ \\
\hline 4 & PSB-POM141 & $1.46 \pm 0.01[22]^{b}$ & $173 \pm 4[22]^{\mathrm{c}}$ \\
\hline \multicolumn{4}{|c|}{ Sulfated algae polysaccharides } \\
\hline 5 & Delesseria sanguinea & $\begin{array}{c}0.0517 \pm 0.0016^{b} \\
(11.1 \mathrm{ng} / \mathrm{mL})\end{array}$ & $\begin{array}{l}1.72 \pm 0.00^{\mathrm{d}} \\
(366 \mathrm{ng} / \mathrm{mL})\end{array}$ \\
\hline 6 & Saccharina latissimi & $\begin{array}{l}0.136 \pm 0.001^{\mathrm{b}} \\
(72.8 \mathrm{ng} / \mathrm{mL})\end{array}$ & $\begin{array}{l}0.408 \pm 0.001^{\mathrm{d}} \\
(218 \mathrm{ng} / \mathrm{mL})\end{array}$ \\
\hline 7 & Fucus vesiculosus & $\begin{array}{l}1.19 \pm 0.00^{\mathrm{b}} \\
(45.2 \mathrm{ng} / \mathrm{mL})\end{array}$ & $\begin{array}{c}12.3 \pm 0.0^{\mathrm{d}} \\
(469 \mathrm{ng} / \mathrm{mL})\end{array}$ \\
\hline 8 & Coccotylus truncatus & $\begin{array}{l}5.33 \pm 0.00^{\mathrm{b}} \\
(682 \mathrm{ng} / \mathrm{mL})\end{array}$ & $\begin{array}{c}16.0 \pm 0.0^{\mathrm{b}} \\
(2045 \mathrm{ng} / \mathrm{mL})\end{array}$ \\
\hline
\end{tabular}

${ }^{\mathrm{a}}$ absorbance-based assay; ${ }^{\mathrm{b}}$ CE-based assay; ${ }^{\mathrm{c}}$ fluorescence polarization (FP) assay; ${ }^{\mathrm{d}}$ malachite-green assay. 

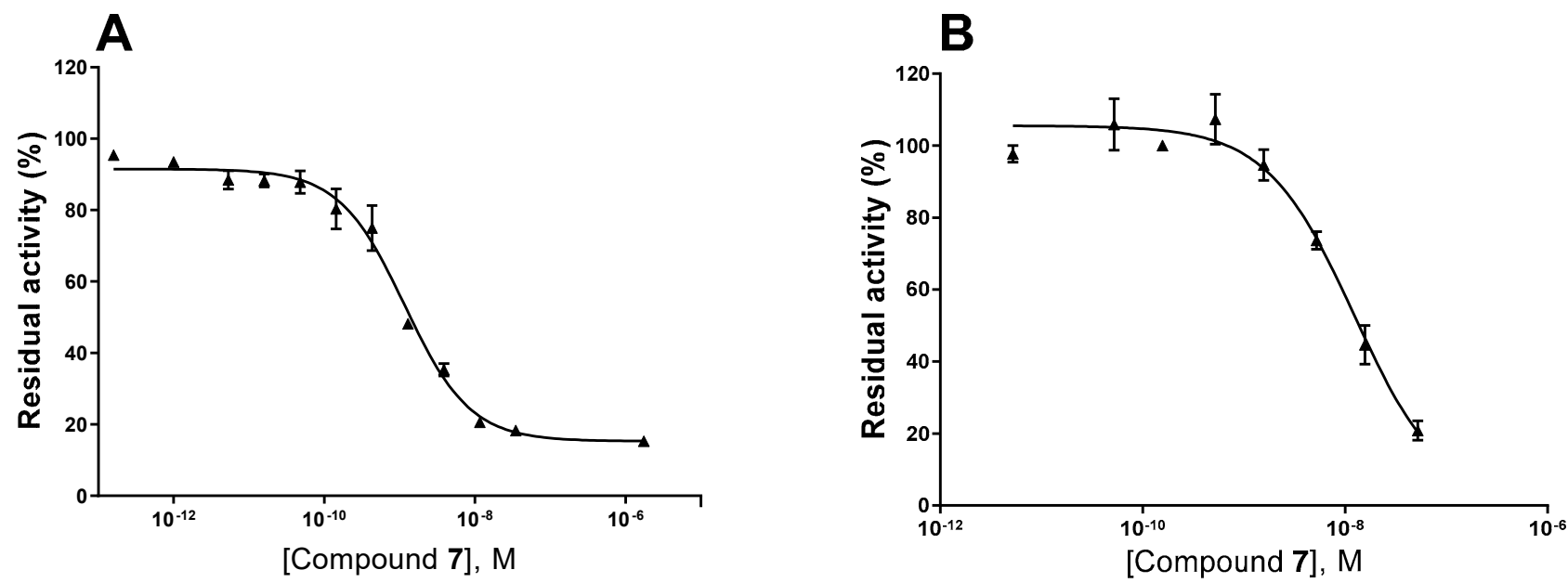

Figure 4. Concentration-inhibition curves of compound 7 at human NPP1 (A) and human CD39 (B). For details see Experimental Section.

Some of the investigated sulfated polysaccharides from sea algae were discovered to be the most potent NPP1 and CD39 inhibitors described to date displaying nano- to subnanomolar potencies. The potency calculated in nmol/L (nM) did not depend on the molecular weight. Sulfated polysaccharide 5 (MW $214 \mathrm{kDa}$ ) was almost 3-fold more potent at NPP1 as compared to compound 6 (MW $534 \mathrm{kDa})$. Compound 5 showed 33fold selectivity for NPP1 over CD39, while $\mathbf{6}$ was about equipotent. Compounds 7 and 8 displayed somewhat lower potency combined with moderate selectivity for NPP1 versus CD39 (see Figure 5). Compound 5 is an extremely potent NPP1 inhibitor with picomolar inhibitory potency at NPP1 $\left(K_{i} 0.0517 \mathrm{nM}\right)$ showing ancillary CD39 inhibition $\left(\mathrm{K}_{\mathrm{i}} 1.72 \mathrm{nM}\right)$, but being highly selective versus all other investigated ectonucleotidases. Sulfated polysaccharide 6 is about equipotent at both NPP1 and CD39, and can be envisaged as a dual NPP1/CD39 inhibitor. Such dual activity could be a big advantage in cancer therapy since both ATP-hydrolyzing enzymes may be upregulated and constitute redundant pathways for nucleotide degradation.

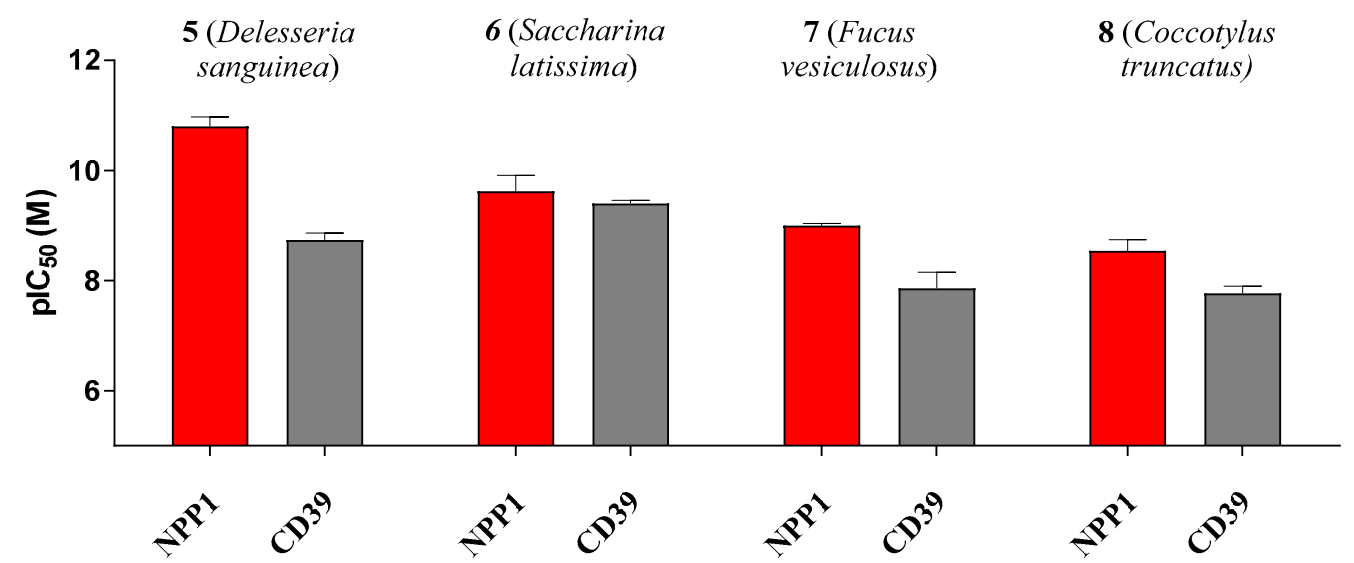

Figure 5. $p \mathrm{IC}_{50}\left(-\log \mathrm{IC}_{50}\right)$ values of compounds 5-8 at the ectonucleotidases NPP1 and CD39 are shown. Error bars represent $\mathrm{SD}$ values. For $\mathrm{IC}_{50}$ values see Table 3.

Next, we studied the inhibition type for compound 7 , the compound with the lowest molecular weight, as a representative for this new class of ectonucleotidase inhibitors using ATP as a substrate. Considering the size of the compounds (with molecular masses ranging from 38 to $534 \mathrm{kDa}$ ) and based on their structures, we presumed an allosteric mechanism of inhibition. The effect of inhibitor 7 on the kinetics of NPP1 and CD39 was investigated. In both cases, the Michaelis-Menten plots (Figure 6A,C) clearly showed a decrease in 
$V_{\max }$ in the presence of the inhibitor, which is indicative of a non-competitive or mixed type of inhibition. Moreover, the apparent $\mathrm{K}_{\mathrm{m}}$ values are increased at higher inhibitor concentrations. The Lineweaver-Burk plot [39] confirmed a non-competitive/mixed type of inhibition (Figure 6B,D) at both enzymes, NPP1 and CD39.

A

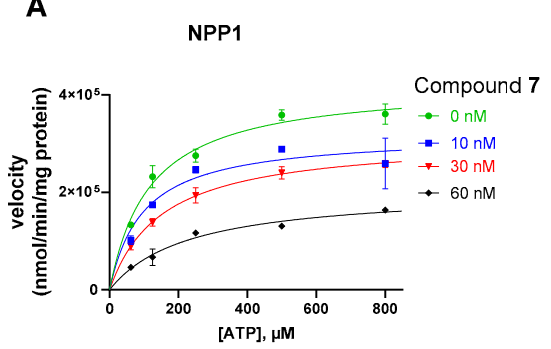

B

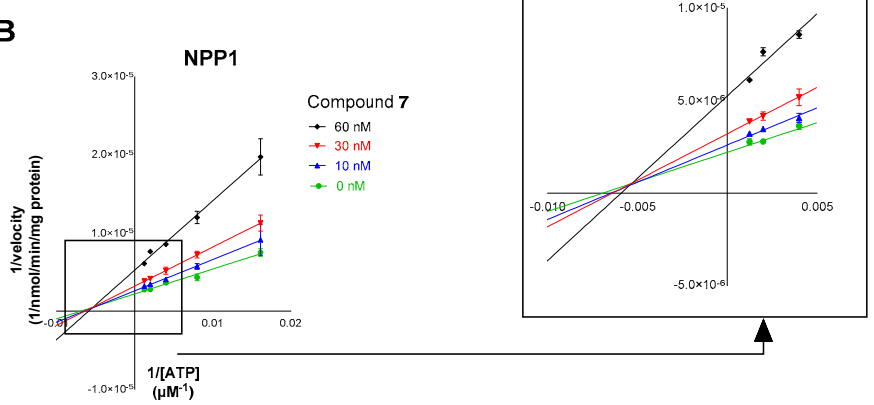

\begin{tabular}{|l|c|c|c|c|}
\hline Compound 7 $(\mathrm{nM})$ & 0 & 10 & 30 & 60 \\
\hline $\mathrm{K}_{\mathrm{m}}$ apparent $(\mu \mathrm{M})$ & 117 & 97.8 & 153 & 230 \\
\hline $\mathrm{V}_{\max }(\mathrm{nmmol} / \mathrm{min} / \mathrm{mg}$ protein $)$ & $4.26 \times 10^{6}$ & $3.17 \times 10^{6}$ & $3.10 \times 10^{6}$ & $2.05 \times 10^{6}$ \\
\hline
\end{tabular}

C

CD39

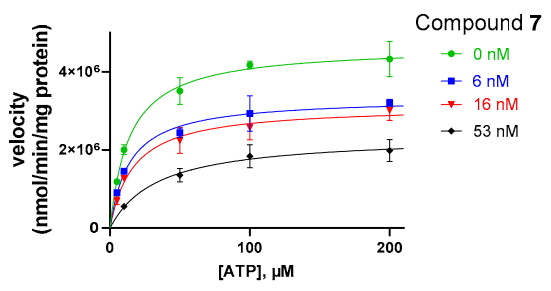

D

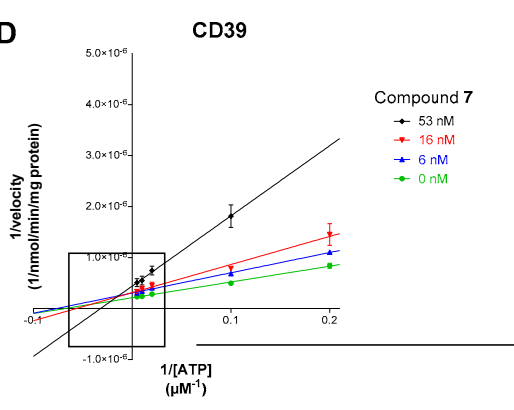

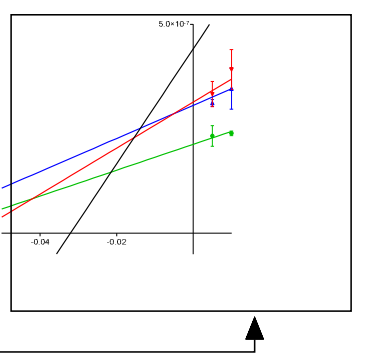

\begin{tabular}{|l|c|c|c|c|}
\hline Compound 7 $(\mathrm{nM})$ & 0 & 6 & 16 & 53 \\
\hline $\mathrm{K}_{\mathrm{m}}$ apparent $(\mu \mathrm{M})$ & 13.9 & 13.9 & 16.7 & 34.1 \\
\hline $\mathrm{V}_{\max }(\mathrm{nmmol} / \mathrm{min} / \mathrm{mg}$ protein $)$ & $4.64 \times 10^{6}$ & $3.33 \times 10^{6}$ & $3.12 \times 10^{6}$ & $2.36 \times 10^{6}$ \\
\hline
\end{tabular}

Figure 6. Investigation of the enzyme inhibition type for inhibitor 7 at NPP1 (A,B) and CD39 (C,D). In (A,C) the MichaelisMenten curves are shown without and in the presence of different concentrations of inhibitor 7 . For the determination of the inhibition type, Lineweaver-Burk plots are shown in (B,D) (see Sections 3.1 and 3.4 for experimental details). The results indicate a non-competitive/mixed type of inhibition. The kinetic parameters of ATP hydrolysis by CD39 and NPP1, respectively, in the absence and presence of inhibitor $\mathbf{7}$ are provided.

Finally, we investigated compound 7 in a more complex cellular system. The human glioblastoma cell line U87 had previously been shown to express NPP1 and CD73 [40-43], but only negligible amounts of CD39 [44]. These enzymes are known to convert ATP to adenosine in a sequential reaction cascade (see Figure 1). Therefore, we used this cancer cell line to determine the hydrolysis of extracellular ATP, added to the cells, resulting in the formation of adenosine, which is known to produce antiproliferative, antiangiogenic, metastasis-promoting and immunosuppressive effects when released into the tumor microenvironment. Dipyridamole was added to block the cellular uptake of adenosine via the SLC29 transporter family [45], and erythro-9-(2-hydroxy-3-nonyl)adenine (EHNA) was present to inhibit metabolism of adenosine to inosine [46]. Cells treated with ATP, dipyridamole and EHNA were studied in the absence and in the presence of sulfopolysaccharide 7 , and extracellular adenosine accumulation was quantified by capillary electrophoresis coupled to UV detection. The results clearly showed a concentration-dependent inhibition of adenosine formation by sulfopolysaccharide 7 in U87 glioma cells, which is assumed to be due to the blockade of NPP1 by inhibitor 7. These data confirmed the strong inhibitory activity of ectonucleotidase inhibitor $\mathbf{7}$ (as a representative of the chemical class of 
sulfopolysaccharides) on the formation of extracellular adenosine from ATP by a human glioblastoma cell line (Figure 7).

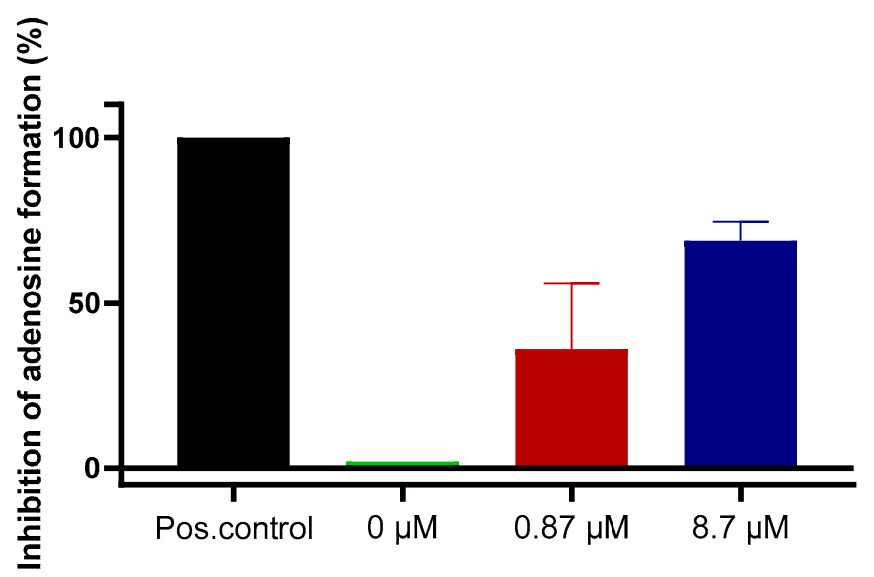

Figure 7. Blockade of extracellular adenosine formation from ATP by compound 7 on human U87 glioblastoma cells. The cells were treated with ATP (ectonucleotidase substrate) and incubated for 3 $\mathrm{h}$ in the presence of dipyridamole to prevent cellular uptake of adenosine, and EHNA to prevent adenosine deamination. Adenosine was quantified by CE-UV. Results represent means of two independent experiments each performed in quadruplicate measurements. Positive (Pos.) control: the potent NPP1 inhibitor PSB-POM141 $(4,10 \mu \mathrm{M})$ or the potent CD73 inhibitor PSB-19316 $(0.1 \mu \mathrm{M})$ were added both of which led to a full blockade of NPP1 and CD73 activity thereby preventing the formation of adenosine. For details see Experimental Section 3.6.

\section{Materials and Methods}

The sulfated polysaccharides 5-8 were isolated from the two brown algae Saccharina latissima (Laminariales, Laminariaceae) (North Atlantic Faroe Island) and Fucus vesiculosus (Fucales, Fucaceae) and the two red algae Delesseria sanguinea (Ceramiales, Delesseriaceae) and Coccotylus truncatus (Gigartinales, Phyllophoraceae) (both collected in the sublittoral habitat of the large artificial reef near Nienhagen (Baltic Sea, Germany). They were extracted, purified and chemically characterized as previously described [32-34], whereby compound 7, fucoidan from Fucus vesiculosus was purchased from Sigma-Aldrich, catalog No. F5631, Lot No SLBC4004 V). In short: the pulverized algal material was defatted with Soxhlet extraction ( $99 \% v / v$ ethanol). The main extraction was performed with demineralized water at $85{ }^{\circ} \mathrm{C}$ for $8 \mathrm{~h}$ (compound 5) and aqueous $2 \% \mathrm{CaCl}_{2}$ at $85^{\circ} \mathrm{C}$ for $2 \mathrm{~h}$ (compounds 6 and 8) (reflux condition). The supernatant was evaporated and precipitated with ethanol (final concentration $60 \% v / v$ ) at $4{ }^{\circ} \mathrm{C}$. Further steps involved centrifugation, dissolving in demineralized water, dialysis and lyophilization. The analyzed chemical parameters included sulfate content and degree of sulfation, weight average molar mass, monosaccharide composition, contents of protein and uronic acids.

\subsection{Chemicals}

Nucleotides (AMP, ADP, ATP and cAMP), nucleosides (adenosine, inosine and uridine), dipyridamole, erythro-9-(2-hydroxy-3-nonyl)adenine (EHNA), disodium hydrogenphosphate and sodium dodecyl sulfate were purchased from Merck KGaA (Darmstadt, Germany). Sodium chloride, potassium chloride, potassium dihydrogen phosphate, sodium hydrogencarbonate, D-glucose, $N$-[2-hydroxyethyl]piperazine- $N$ '-[2-ethanesulfonic acid] (HEPES), calcium chloride and magnesium sulfate were purchased from PAN Biotech GmbH (Aidenbach, Germany). Dulbecco's modified Eagle medium, fetal calf serum (FCS), penicillin/streptomycin (P/S) and L-glutamine were also from PAN Biotech $\mathrm{GmbH}$. 


\subsection{NPP1 Assay}

Recombinant soluble human NPP1 was obtained as previously described [22]. Compounds 5-8 were tested as inhibitors of human NPP1 at a concentration of 20,000 ng/mL vs. ATP $(400 \mu \mathrm{M})$ as a substrate. Subsequent concentration-inhibition curves were performed using several dilutions of the test compounds prepared in assay buffer $(10 \mathrm{mM}$ $\mathrm{N}$-cyclohexyl-2-aminoethanesulfonic acid (CHES), $2 \mathrm{mM} \mathrm{CaCl}_{2}$ and $1 \mathrm{mM} \mathrm{MgCl}_{2}, \mathrm{pH} 9.00$ ). The human NPP1, prepared as previously described [22], was diluted in the assay buffer, and $0.224 \mu \mathrm{g}$ of the enzyme were employed per vial. The mixture was incubated for $30 \mathrm{~min}$ at $37^{\circ} \mathrm{C}$, and the reaction was terminated by heating at $90^{\circ} \mathrm{C}$ for $5 \mathrm{~min}$. After cooling down on ice, analysis was carried out using capillary electrophoresis (CE). Positive and negative controls were studied in parallel. Data collection and peak area analysis were performed by the P/ACE MDQ software 32 KARAT obtained from Beckman Coulter (Fullerton, CA, USA). A polyacrylamide-coated capillary was used $(30 \mathrm{~cm}(20 \mathrm{~cm}$ effective length) $\times 50 \mu \mathrm{m}$ (id) $\times 360 \mu \mathrm{m}$ (od) purchased from Chromatographie Service $\mathrm{GmbH}$ (Langerwehe, Germany)). Samples were injected electrokinetically by applying a voltage of $-6 \mathrm{kV}$ for $30 \mathrm{~s}$. Finally, analytes were separated by applying a separation voltage of $-20 \mathrm{kV}$, and detected by $U V$ at $260 \mathrm{~nm}$. The $I C_{50}$ values were determined by nonlinear curve fitting using the GraphPad Prism software 7.0. The mechanism of inhibition of human NPP1 was determined by employing different concentrations of the inhibitor $(0,10,30$ and $60 \mathrm{nM}$ ) vs. five different substrate concentrations ranging from 62 to $800 \mu \mathrm{M}$ ATP. The assay procedure and operation conditions were the same as described above. The experiments were conducted two times, each in triplicates. A Lineweaver-Burk was calculated using GraphPad Prism 7.0 for predicting the inhibition type of the inhibitor.

\subsection{NPP3 Assay}

Recombinant soluble human NPP3 was obtained as previously described [47]. Compounds 5-8 were screened at a concentration of $20,000 \mathrm{ng} / \mathrm{mL}$ vs. $400 \mu \mathrm{M} p-\mathrm{Nph}-5^{\prime}-\mathrm{TMP}$ to study a potential inhibition of NPP3, using a colorimetric assay as previously described [38]. Soluble, purified human NPP3 was diluted in the assay buffer $(50 \mathrm{mM}$ TRIS $\mathrm{HCl}, 2 \mathrm{mM}$ $\mathrm{CaCl}_{2}$ and $0.2 \mathrm{mM} \mathrm{ZnCl}_{2} \mathrm{pH} 9.00$ ), and $0.45 \mu \mathrm{g}$ of enzyme per vial was used. The mixture was incubated for $30 \mathrm{~min}$ at $37^{\circ} \mathrm{C}$, and the reactions were subsequently terminated by adding $20 \mu \mathrm{L}$ of $1.0 \mathrm{~N} \mathrm{NaOH}$. The assay is based on the enzymatic ester hydrolysis of $p$-Nph-5'-TMP that results in the formation of $p$-nitrophenolate. The absorption maximum was measured at $400 \mathrm{~nm}$ using a BMG PheraStar FS plate reader (BMG Labtech $\mathrm{GmbH}$, Ortenberg, Germany). Each analysis was repeated three times in triplicate measurements.

\subsection{NPP4 Assay}

Recombinant human soluble NPP4 was obtained as previously described [48]. Screening of the test compounds 5-8 was performed at a concentration of $20,000 \mathrm{ng} / \mathrm{mL}$ versus $20 \mu \mathrm{M}$ of $\mathrm{Ap}_{4} \mathrm{~A}$ as a substrate employing a previously described luminescence-based assay [48]. The assay buffer consisted of $10 \mathrm{mM}$ HEPES, $1 \mathrm{mM} \mathrm{MgCl} 2$ and $2 \mathrm{mM} \mathrm{CaCl}_{2}$ ( $\mathrm{pH}$ 8.0). The enzyme reaction was started by adding $0.14 \mu \mathrm{g}$ of human purified NPP4 to the reaction mixture which was incubated at $37^{\circ} \mathrm{C}$ for $60 \mathrm{~min}$. The released product, ATP, was quantified using the luciferin-luciferase reaction. The firefly luciferase reacts with D-luciferin in the presence of the formed ATP and $\mathrm{Mg}^{2+}$, which act as cofactors. The resulting luminescence correlates to the enzyme activity. It was measured at $560 \mathrm{~nm}$ using a microplate reader (BMG PheraStar, Labtech GmbH, Ortenberg, Baden-Württemberg, Germany). Three independent experiments were performed, each in duplicates with positive and negative controls studied in parallel.

\subsection{NTPDase Assays}

Human NTPDases (subtypes 1, 2, 3 and 8) were recombinantly expressed as previously described and cell membrane preparations overexpressing one of the NTPDase subtypes were used for the experiments according to described procedures [46]. For monitoring 
the inhibitory activity of the compounds at the NTPDases two different assay system were utilized. The malachite green assay was used for the determination of NTPDase1 (CD39) concentration-inhibition curves with compound 5-7 and for the determination of the inhibition type of compound 7 . The CE-based assay was utilized for selectivity studies of compound 5-8 at NTPDase2, NTPDase3 and NTPDase8, and for the determination of concentration-inhibition curves for compound 8 at human CD39. The test compounds were investigated at $20,000 \mathrm{ng} / \mathrm{mL}$ for initial screening, and subsequently at different concentrations for obtaining concentration-inhibition curves. The enzyme amounts were selected after enzymatic titration and adjusted to ensure a conversion rate of $10-20 \%$; for NTPDase1 assays, $0.1 \mu \mathrm{g}$ of human umbilical cord membrane preparation [49,50] was employed per vial, for NTPDase 2 assays, $0.07 \mu \mathrm{g}$ of recombinant enzyme was used, for NTPDase3 assays, $0.45 \mu \mathrm{g}$ of enzyme was employed and for NTPDase8 assays, $0.52 \mu \mathrm{g}$ of enzyme was utilized. Human NTPDase $1,-2,-3$ and -8 were expressed as previously described $[49,50]$. When the malachite assay was used, the reaction was initiated by the addition of $50 \mu \mathrm{M}$ ATP $\left(K_{m}\right.$ (NTPDase1) $\left.=17 \mu \mathrm{M}\right)$ [50]. The reaction buffer consisted of $10 \mathrm{mM}$ HEPES, $2 \mathrm{mM} \mathrm{CaCl}_{2}$ and $1 \mathrm{mM} \mathrm{MgCl}_{2}$, $\mathrm{pH}$ 7.4. The enzyme reaction mixture was incubated at $37^{\circ} \mathrm{C}$ for $15 \mathrm{~min}$. The released phosphate was quantified by adding malachite-green and molybdate reagents, incubating for $20 \mathrm{~min}$ at room temperature, and measuring the UV-absorption at $600 \mathrm{~nm}$ [51]. The prediction of the mechanism of inhibition at human NTPDase 1 was determined for compound 7 as a representative example employing different concentrations of the investigated inhibitor $(0,6,16$ and $53 \mathrm{nM}$ of 7) vs. five different substrate concentrations of ATP (from 5 to $200 \mu \mathrm{M}$ ). The assay procedure and operation conditions were the same as described above. A Lineweaver-Burk plot was calculated using GraphPad Prism 7.0 for predicting the inhibition type of the compound. In the CE assay, the selected substrate concentration of ATP was $100 \mu \mathrm{M}$ for human NTPDase2, -3 and -8 . The reaction buffer was the same as for NTPDase1 described above. The mixtures of enzyme with the substrate and test compound were incubated at $37^{\circ} \mathrm{C}$ for $30 \mathrm{~min}$, and the enzymatic reaction was stopped by heating it for $10 \mathrm{~min}$ at $95^{\circ} \mathrm{C}$. The released products were separated by capillary electrophoresis and quantified by their UV-absorption at $260 \mathrm{~nm}$ in the presence of ADP and AMP as external standards as previously described [48]. Positive and negative controls were studied in parallel.

\subsection{CD73 Assay}

Soluble human CD73 was recombinantly expressed and purified as described [52], and the assays were performed according to a described procedure [53]. The enzymatic reaction was performed by mixing $0.36 \mathrm{ng}$ of human CD73 [52], with the test compound $(20,000 \mathrm{ng} / \mathrm{mL})$ in the assay buffer $(25 \mathrm{mM}$ Tris, $140 \mathrm{mM}$ sodium chloride and $25 \mathrm{mM}$ sodium dihydrogenphosphate, $\mathrm{pH} 7.4$ ), and $5 \mu \mathrm{M}$ of $\left[2,8^{-3} \mathrm{H}\right] \mathrm{AMP}$ (specific activity $7.4 \times 10^{8} \mathrm{~Bq} / \mathrm{mmol}, 20 \mathrm{mCi} / \mathrm{mmol}$, American Radio-labeled Chemicals, MO, USA, distributed by Hartmann Analytic, Germany) was added. The enzymatic reaction was performed for $25 \mathrm{~min}$ at $37^{\circ} \mathrm{C}$ in a shaking water bath. Then, $500 \mu \mathrm{L}$ of cold precipitation buffer (100 mM lanthanum chloride and $100 \mathrm{mM}$ sodium acetate, $\mathrm{pH} 4.00$ ) was added to stop the reaction and to facilitate precipitation of free phosphate and unconverted $\left[2,8-{ }^{3} \mathrm{H}\right] \mathrm{AMP}$. After the precipitation was completed (after at least $30 \mathrm{~min}$ on ice), the mixture was separated by filtration through GF/B glass fiber filters using a cell harvester (M-48, Brandel, MD, USA). After washing each reaction vial three times with $400 \mu \mathrm{L}$ of cold $\left(4^{\circ} \mathrm{C}\right)$ demineralized water, $5 \mathrm{~mL}$ of the scintillation cocktail (ULTIMA Gold XR, PerkinElmer, MA, USA) was added, and the radioactivity was measured by scintillation counting (TRICARB 2900 TR, Packard/PerkinElmer; counting efficacy: $49-52 \%)$. Positive and negative controls were tested in parallel.

\subsection{Experiments on U87 Glioblastoma Cells}

U87 glioblastoma cells were grown in cell culture flasks until reaching a confluent cell layer. Cells were cultivated at $37{ }^{\circ} \mathrm{C}$ and $5 \% \mathrm{CO}_{2}$ in Dulbecco's modified Eagle medium 
(DMEM) with additions of 10\% FCS, 1\% penicillin/streptomycin and 1\% L-glutamine. The cells were rinsed with phosphate-buffered saline (PBS) and detached with ethylenediaminetetraacetic acid (EDTA). Thereafter, they were counted in a cell counter (CASY ${ }^{\circledR}$ 1 Model TT, Schärfe System GmbH, Reutlingen, Germany), then rinsed three times with PBS before they were resuspended in Krebs-HEPES buffer at a concentration of $1 \times 10^{6}$ cells $/ \mathrm{mL}$ per well [54]. Cells ( $1 \mathrm{~mL}$ of a cell suspension containing $10^{6}$ cells) were then pipetted into each well of a 24-well plate (Sarstedt AG, Nümbrecht, Germany). Subsequently, the cells were pretreated with dipyridamole $(20 \mu \mathrm{M})$ for $30 \mathrm{~min}$ to block nucleoside transport. Adenosine deaminase (ADA) activity was inhibited by the addition of $1 \mu \mathrm{M}$ of the inhibitor EHNA, which was added to each sample, and controls [4]. Thereafter, inhibitor 7 was added, and the samples were incubated with $300 \mu \mathrm{M}$ of ATP for $3 \mathrm{~h}$. Then, an aliquot of $230 \mu \mathrm{L}$ of solution from each vial was transferred to $1.5 \mathrm{~mL}$ Eppendorf tubes, and heated at $95^{\circ} \mathrm{C}$ for $10 \mathrm{~min}$ to inactivate the enzymes in order to avoid further nucleotide degradation. Before performing capillary electrophoresis (CE) measurements, the samples were centrifuged at $600 \times g$ to remove insoluble material like cell debris from the supernatant. Until CE measurement, the supernatants were stored at $-20^{\circ} \mathrm{C}$. Nucleotides (ATP, ADP, AMP and CAMP) and nucleosides (adenosine, inosine and uridine), which were also used as standards to monitor efficient separation by CE, were dissolved in Krebs-HEPES buffer at a concentration of $10 \mu \mathrm{M}$ [54] and stored at $-20^{\circ} \mathrm{C}$ as well. For analysis of the formed products, CE measurements were performed according to published procedures [55].

\section{Conclusions}

In conclusion, we identified sulfopolysaccharides isolated from sea algae to act as extremely potent, noncompetitive inhibitors of the ectonucleotidases NPP1 and CD39 with somewhat higher inhibitory potency against NPP1. Both of these enzymes catalyze the hydrolysis of proinflammatory, antiproliferative ATP yielding, in concert with the AMP-hydrolyzing ectoenzyme CD73, adenosine, which displays immunosuppressive and tumor-promoting activities. In fact, we observed reduced formation of adenosine in human glioblastoma U87 cells treated with a representative example of the investigated sulfopolysaccharides. These effects might explain or at least contribute to the previously observed anticancer effects of sulfated algae polysaccharides from sea weeds, which were shown to be non-toxic and well tolerated by humans. The sulfate groups are believed to be essential for their ectonucleotidase-inhibitory effects because other negatively charged compounds, e.g., some polyoxometalates, can also inhibit these ATP-hydrolyzing enzymes with high potency. The substrate ATP itself is also a negatively charged compound, and the enzymes may therefore preferably recognize negatively charged molecules. While ATP would subsequently be guided to the substrate binding pocket, the large anionic polymers and cluster compounds likely remain attached to the initial recognition site at the surface of the enzymes showing allosteric inhibition. In future studies, we plan to investigate the role of the sulfate groups on the seaweed polysaccharides for their enzyme-inhibitory potency by investigating derivatives without or with lower degrees of sulfation.

Author Contributions: C.E.M. designed the study; V.L. performed the experiments on NPP1, NPP4, NTPDase2, 3 and NTPDase8; L.S. performed the experiments on NTPDase 1; H.J.M.S. and M.S.S. performed and analyzed the data of the cell based-assay under the supervision of G.B.; S.M. performed the experiments on NPP3; C.R. performed the experiments on CD73; V.L., S.-Y.L., L.S., S.M., C.R. analyzed the data under the supervision of C.E.M.; S.A. provided the compounds; J.S. and J.P. provided NTPDase preparations; V.L. and C.E.M. wrote the manuscript with contributions by all coauthors. All authors have read and agreed to the published version of the manuscript.

Funding: This study was funded by the Federal Ministry of Education and Research (BMBF, BIGS DrugS project) and by the Deutsche Forschungsgemeinschaft (DFG, German Research Foundation)Project-ID: 335447717-SFB 1328. J.S. received support from the Natural Sciences and Engineering Research Council of Canada (NSERC; RGPIN-2016-05867). 
Institutional Review Board Statement: Human umbilical cords as a source of CD39 were obtained under approved institutional review board protocol (Comité d'Éthique de la Recherche du CHU de Québec-Université Laval) following written consent.

Informed Consent Statement: Not applicable.

Data Availability Statement: The data presented in this study are available on request from the corresponding author. The data are not publicly available due to privacy reasons.

Acknowledgments: We are grateful to Holger Stephan, Helmholtz-Zentrum Dresden-Rossendorf (HZDR), for the gift of PSB-POM141.

Conflicts of Interest: The authors declare no conflict of interest. The funders had no role in the design of the study; in the collection, analyses, or interpretation of data; in the writing of the manuscript, or in the decision to publish the results.

\begin{tabular}{|c|c|}
\hline $\mathrm{Ap}_{4} \mathrm{~A}$ & diadenosine tetraphosphate \\
\hline CD & cluster of differentiation \\
\hline CE & capillary electrophoresis \\
\hline CHES & $N$-cyclohexyl-2-aminoethanesulfonic acid \\
\hline CD39 & nucleoside triphosphate diphosphohydrolase-1 \\
\hline CD73 & ecto- $5^{\prime}$-nucleotidase \\
\hline DAD & diode array detector \\
\hline DMEM & Dulbecco's Modified Eagle Medium \\
\hline EDTA & ethylenediaminetetraacetic acid \\
\hline EHNA & erythro-9-(2-hydroxy-3-nonyl)-adenine \\
\hline HEPES & 4-(2-hydroxyethyl)piperazine-1-ethanesulfonic acid \\
\hline NTPDase1 & nucleoside triphosphate diphosphohydrolase-1 \\
\hline NPP1 & nucleotide pyrophosphatase/phosphodiesterase-1 (CD203a) \\
\hline $\mathrm{pIC}_{50}$ & negative log of the half-maximal inhibitory concentration \\
\hline PBS & phosphate-buffered saline \\
\hline$p \mathrm{NP}-\mathrm{TMP}$ & p-nitrophenyl thymidine 5-monophosphate \\
\hline PSB & Pharmaceutical Sciences Bonn \\
\hline SDS & sodium dodecylsulfate \\
\hline
\end{tabular}

\section{References}

1. Hara, H.; Takeda, N.; Komuro, I. Pathophysiology and therapeutic potential of cardiac fibrosis. Inflamm. Regen. 2017, 37, 13. [CrossRef] [PubMed]

2. Abbracchio, M.P.; Burnstock, G.; Boeynaems, J.-M.; Barnard, E.A.; Boyer, J.L.; Kennedy, C.; Knight, G.E.; Fumagalli, M.; Gachet, C.; Jacobson, K.A.; et al. International Union of Pharmacology LVIII: Update on the P2Y G protein-coupled nucleotide receptors: From molecular mechanisms and pathophysiology to therapy. Pharmacol. Rev. 2006, 58, 281-341. [CrossRef] [PubMed]

3. Coddou, C.; Yan, Z.; Obsil, T.; Pablo Huidobro-Toro, J.; Stojilkovic, S.S. Activation and regulation of purinergic P2X receptor channels. Pharmacol. Rev. 2011, 63, 641-683. [CrossRef] [PubMed]

4. Antonioli, L.; Blandizzi, C.; Pacher, P.; Haskó, G. The purinergic system as a pharmacological target for the treatment of immune-mediated inflammatory diseases. Pharmacol. Rev. 2019, 71, 345-382. [CrossRef]

5. Vitiello, L.; Gorini, S.; Rosano, G.; La Sala, A. Immunoregulation through extracellular nucleotides. Blood 2012, 120, 511-518. [CrossRef]

6. Allard, B.; Longhi, M.S.; Robson, S.C.; Stagg, J. The ectonucleotidases CD39 and CD73: Novel checkpoint inhibitor targets. Immunol. Rev. 2017, 276, 121-144. [CrossRef]

7. Onyedibe, K.I.; Wang, M.; Sintim, H.O. ENPP1, an old enzyme with new functions, and small molecule inhibitors-A STING in the tale of ENPP1. Molecules 2019, 24, 4192. [CrossRef]

8. Zimmermann, H.; Zebisch, M.; Sträter, N. Cellular function and molecular structure of ecto-nucleotidases. Purinergic Signal. 2012, 8, 437-502. [CrossRef]

9. Lee, S.-Y.; Müller, C.E. Nucleotide pyrophosphatase/phosphodiesterase 1 (NPP1) and its inhibitors. MedChemComm 2017, 8, 823-840. [CrossRef]

10. Namasivayam, V.; Lee, S.Y.; Müller, C.E. The promiscuous ectonucleotidase NPP1: Molecular insights into substrate binding and hydrolysis. Biochim. Biophys. Acta Gen. Subj. 2017, 1861, 603-614. [CrossRef] 
11. Albright, R.A.; Ornstein, D.L.; Cao, W.; Chang, W.C.; Robert, D.; Tehan, M.; Hoyer, D.; Liu, L.; Stabach, P.; Yang, G.; et al. Molecular basis of purinergic signal metabolism by ectonucleotide pyrophosphatase/phosphodiesterases 4 and 1 and implications in stroke. J. Biol. Chem. 2014, 289, 3294-3306. [CrossRef] [PubMed]

12. Kato, K.; Nishimasu, H.; Oikawa, D.; Hirano, S.; Hirano, H.; Kasuya, G.; Ishitani, R.; Tokunaga, F.; Nureki, O. Structural insights into cGAMP degradation by Ecto-nucleotide pyrophosphatase phosphodiesterase 1. Nat. Commun. 2018, 9, 4424. [CrossRef] [PubMed]

13. Gorelik, A.; Randriamihaja, A.; Illes, K.; Nagar, B. A key tyrosine substitution restricts nucleotide hydrolysis by the ectoenzyme NPP5. FEBS J. 2017, 5, 1-9. [CrossRef] [PubMed]

14. Hay, C.M.; Sult, E.; Huang, Q.; Mulgrew, K.; Fuhrmann, S.R.; McGlinchey, K.A.; Hammond, S.A.; Rothstein, R.; Rios-Doria, J.; Poon, E.; et al. Targeting CD73 in the tumor microenvironment with MEDI9447. Oncoimmunology 2016, 5, 1-10. [CrossRef] [PubMed]

15. Di Virgilio, F.; Sarti, A.C.; Coutinho-Silva, R. Purinergic signaling, DAMPs, and inflammation. Am. J. Physiol. Cell Physiol. 2020, 318, C832-C835. [CrossRef]

16. Crack, B.E.; Pollard, C.E.; Beukers, M.W.; Roberts, S.M.; Hunt, S.F.; Ingall, A.H.; McKechnie, K.C.; IJzerman, A.P.; Leff, P. Pharmacological and biochemical analysis of FPL 67156, a novel, selective inhibitor of ecto-ATPase. Br. J. Pharmacol. 1995, 114, 475-481. [CrossRef]

17. Schäkel, L.; Schmies, C.C.; Idris, R.M.; Luo, X.; Lee, S.-Y.; Lopez, V.; Mirza, S.; Vu, T.H.; Pelletier, J.; Sévigny, J.; et al. Nucleotide ana$\log$ ARL67156 as a lead structure for the development of CD39 and Dual CD39/CD73 ectonucleotidase inhibitors. Front. Pharmacol. 2020, 11. [CrossRef]

18. Iqbal, J.; Vollmayer, P.; Braun, N.; Zimmermann, H.; Müller, C.E. A capillary electrophoresis method for the characterization of ecto-nucleoside triphosphate diphosphohydrolases (NTPDases) and the analysis of inhibitors by in-capillary enzymatic microreaction. Purinergic Signal. 2005, 1, 349-358. [CrossRef]

19. Baqi, Y.; Weyler, S.; Iqbal, J.; Zimmermann, H.; Müller, C.E. Structure-Activity relationships of anthraquinone derivatives derived from bromaminic acid as inhibitors of ectonucleoside triphosphate diphosphohydrolases (E-NTPDases). Purinergic Signal. 2009, 5, 91-106. [CrossRef]

20. Iqbal, J.; Lévesque, S.A.; Sévigny, J.; Müller, C.E. A highly sensitive CE-UV method with dynamic coating of silica-fused capillaries for monitoring of nucleotide pyrophosphatase/phosphodiesterase reactions. Electrophoresis 2008, 29, 3685-3693. [CrossRef]

21. Müller, C.E.; Iqbal, J.; Baqi, Y.; Zimmermann, H.; Röllich, A.; Stephan, H. Polyoxometalates-A new class of potent ecto-nucleoside triphosphate diphosphohydrolase (NTPDase) inhibitors. Bioorg. Med. Chem. Lett. 2006, 16, 5943-5947. [CrossRef] [PubMed]

22. Lee, S.Y.; Fiene, A.; Li, W.; Hanck, T.; Brylev, K.A.; Fedorov, V.E.; Lecka, J.; Haider, A.; Pietzsch, H.J.; Zimmermann, H.; et al. Polyoxometalates-Potent and selective ecto-nucleotidase inhibitors. Biochem. Pharmacol. 2015, 93, 171-181. [CrossRef] [PubMed]

23. Fernando, I.P.S.; Sanjeewa, K.K.A.; Lee, H.G.; Kim, H.S.; Vaas, A.P.J.P.; De Silva, H.I.C.; Nanayakkara, C.M.; Abeytunga, D.T.U.M.; Lee, D.S.; Lee, J.S.; et al. Fucoidan purified from Sargassum polycystum induces apoptosis through mitochondria-mediated pathway in HL-60 and MCF-7 cells. Mar. Drugs 2020, 18, 196. [CrossRef] [PubMed]

24. Oliveira, C.; Neves, N.M.; Reis, R.L.; Martins, A.; Silva, T.H. A review on fucoidan antitumor strategies: From a biological active agent to a structural component of fucoidan-based systems. Carbohydr. Polym. 2020, 239, 116131. [CrossRef]

25. Peñalver, R.; Lorenzo, J.M.; Ros, G.; Amarowicz, R.; Pateiro, M.; Nieto, G. Seaweeds as a functional ingredient for a healthy diet. Mar. Drugs 2020, 18, 301. [CrossRef]

26. Bittkau, K.S.; Dörschmann, P.; Blümel, M.; Tasdemir, D.; Roider, J.; Klettner, A.; Alban, S. Comparison of the effects of fucoidans on the cell viability of tumor and non-tumor cell lines. Mar. Drugs 2019, 17, 441. [CrossRef]

27. Martínez Andrade, K.A.; Lauritano, C.; Romano, G.; Ianora, A. Marine microalgae with anti-cancer properties. Mar. Drugs 2018, 16, 165. [CrossRef]

28. van Weelden, G.; Bobiński, M.; Okła, K.; van Weelden, W.J.; Romano, A.; Pijnenborg, J.M.A. Fucoidan structure and activity in relation to anti-cancer mechanisms. Mar. Drugs 2019, 17, 32. [CrossRef]

29. Kiddane, A.T.; Kim, G.D. Anticancer and immunomodulatory effects of polysaccharides. Nutr. Cancer 2020. [CrossRef]

30. Lin, Y.; Qi, X.; Liu, H.; Xue, K.; Xu, S.; Tian, Z. The anti-cancer effects of fucoidan: A review of both in vivo and in vitro investigations. Cancer Cell Int. 2020, 20, 154. [CrossRef]

31. Techel, I.; Lahrsen, E.; Alban, S. Degraded fucoidan fractions and $\beta$-1,3-glucan sulfates inhibit CXCL12-induced Erk1/2 activation and chemotaxis in Burkitt lymphoma cells. Int. J. Biol. Macromol. 2020, 143, 968-976. [CrossRef] [PubMed]

32. Grünewald, N.; Alban, S. Optimized and standardized isolation and structural characterization of anti-inflammatory sulfated polysaccharides from the red alga Delesseria sanguinea (Hudson) Lamouroux (Ceramiales, Delesseriaceae). Biomacromolecules 2009, 10, 2998-3008. [CrossRef] [PubMed]

33. Ehrig, K.; Alban, S. Sulfated galactofucan from the brown alga Saccharina latissimi-Variability of yield, structural composition and bioactivity. Mar. Drugs 2014, 13, 76-101. [CrossRef] [PubMed]

34. Lahrsen, E.; Schoenfeld, A.-K.; Alban, S. Degradation of eight sulfated polysaccharides extracted from red and brown algae and its impact on structure and pharmacological activities. ACS Biomater. Sci. Eng. 2019, 5, 1200-1214. [CrossRef]

35. Allen, J.; Brock, S.A. Tailoring the message. Minn. Med. 2000, 83, 45-48.

36. Filisetti-Cozzi, T.M.C.C.; Carpita, N.C. Measurement of uronic acids without interference from neutral sugars. Anal. Biochem. 1991, 197, 157-162. [CrossRef] 
37. Blakeney, A.B.; Harris, P.J.; Henry, R.J.; Stone, B.A. A simple and rapid preparation of alditol acetates for monosaccharide analysis. Carbohydr. Res. 1983, 113, 291-299. [CrossRef]

38. Lee, S.Y.; Sarkar, S.; Bhattarai, S.; Namasivayam, V.; De Jonghe, S.; Stephan, H.; Herdewijn, P.; El-Tayeb, A.; Müller, C.E. SubstrateDependence of competitive nucleotide pyrophosphatase/phosphodiesterase1 (NPP1) inhibitors. Front. Pharmacol. 2017,8 , 1-7. [CrossRef]

39. Lineweaver, H.; Burk, D. The Determination of enzyme dissociation constants. J. Am. Chem. Soc. 1934, 56, 658-666. [CrossRef]

40. Grobben, B.; De Deyn, P.; Slegers, H. Rat C6 glioma as experimental model system for the study of glioblastoma growth and invasion. Cell Tissue Res. 2002, 310, 257-270. [CrossRef]

41. Aerts, I.; Martin, J.J.; De Deyn, P.P.; Van Ginniken, C.; Van Ostade, X.; Kockx, M.; Dua, G.; Slegers, H. The expression of ectonucleotide pyrophosphatase/phosphodiesterase 1 (E-NPP1) is correlated with astrocytic tumor grade. Clin. Neurol. Neurosurg. 2011, 113, 224-229. [CrossRef] [PubMed]

42. Gõmez-Villafuertes, R.; Pintor, J.; Miras-Portugal, M.T.; Gualix, J. Ectonucleotide pyrophosphatase/phosphodiesterase activity in neuro-2a neuroblastoma cells: Changes in expression associated with neuronal differentiation. J. Neurochem. 2014, 131, 290-302. [CrossRef]

43. Bageritz, J.; Puccio, L.; Piro, R.M.; Hovestadt, V.; Phillips, E.; Pankert, T.; Lohr, J.; Herold-Mende, C.; Lichter, P.; Goidts, V. Stem cell characteristics in glioblastoma are maintained by the ecto-nucleotidase E-NPP1. Cell Death Differ. 2014, 21, 929-940. [CrossRef] [PubMed]

44. Xu, S.; Shao, Q.Q.; Sun, J.T.; Yang, N.; Xie, Q.; Wang, D.H.; Huang, Q.B.; Huang, B.; Wang, X.Y.; Li, X.G.; et al. Synergy between the ectoenzymes CD39 and CD73 contributes to adenosinergic immunosuppression in human malignant gliomas. Neuro Oncol. 2013, 15, 1160-1172. [CrossRef]

45. Pastor-Anglada, M.; Pérez-Torras, S. Who is who in adenosine transport. Front. Pharmacol. 2018, 9, 1-10. [CrossRef]

46. Poppe, D.; Doerr, J.; Schneider, M.; Wilkens, R.; Steinbeck, J.A.; Ladewig, J.; Tam, A.; Paschon, D.E.; Gregory, P.D.; Reik, A.; et al. Genome editing in neuroepithelial stem cells to generate human neurons with high adenosine-releasing capacity. Stem Cells Transl. Med. 2018, 7, 477-486. [CrossRef] [PubMed]

47. Gorelik, A.; Randriamihaja, A.; Illes, K.; Nagar, B. Structural basis for nucleotide recognition by the ectoenzyme CD203c. FEBS J. 2018, 285, 2481-2494. [CrossRef] [PubMed]

48. Lopez, V.; Lee, S.-Y.; Stephan, H.; Müller, C.E. Recombinant expression of ecto-nucleotide pyrophosphatase/phosphodiesterase 4 (NPP4) and development of a luminescence-based assay to identify inhibitors. Anal. Biochem. 2020, 603, 113774. [CrossRef] [PubMed]

49. Lévesque, S.A.; Lavoie, É.G.; Lecka, J.; Bigonnesse, F.; Sévigny, J. Specificity of the ecto-ATPase inhibitor ARL 67156 on human and mouse ectonucleotidases. Br. J. Pharmacol. 2007, 152, 141-150. [CrossRef]

50. Kukulski, F.; Lévesque, S.A.; Lavoie, E.G.; Lecka, J.; Bigonnesse, F.; Knowles, A.F.; Robson, S.C.; Kirley, T.L.; Sévigny, J. Comparative hydrolysis of P2 receptor agonists by NTPDases 1, 2, 3 and 8. Purinergic Signal. 2005, 1, 193-204. [CrossRef]

51. Cogan, E.B.; Birrell, G.B.; Griffith, O.H. A robotics-Based automated assay for inorganic and organic phosphates. Anal. Biochem. 1999, 271, 29-35. [CrossRef] [PubMed]

52. Junker, A.; Renn, C.; Dobelmann, C.; Namasivayam, V.; Jain, S.; Losenkova, K.; Irjala, H.; Duca, S.; Balasubramanian, R.; Chakraborty, S.; et al. Structure-Activity relationship of purine and pyrimidine nucleotides as ecto- $5^{\prime}$-nucleotidase (CD73) inhibitors. J. Med. Chem. 2019, 62, 3677-3695. [CrossRef] [PubMed]

53. Freundlieb, M.; Zimmermann, H.; Müller, C.E. A new, sensitive ecto-5-nucleotidase assay for compound screening. Anal. Biochem. 2014, 446, 53-58. [CrossRef] [PubMed]

54. Qurishi, R.; Kaulich, M.; Müller, C.E. Fast, efficient capillary electrophoresis method for measuring nucleotide degradation and metabolism. J. Chromatogr. A 2002, 952, 275-281. [CrossRef]

55. Kaulich, M.; Qurishi, R.; Müller, C.E. Extracellular metabolism of nucleotides in neuroblastoma x glioma NG108-15 cells determined by capillary electrophoresis. Cell. Mol. Neurobiol. 2003, 23, 349-364. [CrossRef] 